\title{
A Numerical General Equilibrium Model with Endogenous Formation of Trading Blocs
}

\author{
Timothy C.G. Fisher \\ University of Sydney \\ Robert G. Waschik \\ La Trobe University
}

\begin{abstract}
We are interested in whether Preferential Trade Agreements facilitate attainment of Global Free Trade. Using a numerical general equilibrium model based on global trade data aggregated to 5 regions and 12 goods, we calculate the optimal tariffs in a Nash tariff-setting game when regions are free to form trading blocs. Using Riezman's (1999) notion of blocking coalitions, we determine endogenously whichtradingbloc structures emerge when regions can form Free Trade Areas or Customs Unions. We nd that Global Free Trade may not be an equilibrium outcome unless constraints are placed on the way Customs Unions set their Common External Tariffs.
\end{abstract}

- JEL classification: F15, F13, C68

- Keywords: Endogenous coalition formation, Preferential trade agreements

\section{Introduction}

The proliferation of Preferential Trade Agreements (PTAs) in recent years has again raised the issue of whether regional free-trade blocs help or hinder the ultimate objective of global free trade. Notwithstanding the political pressures that

\footnotetext{
*Corresponding address: Robert Waschik Department of Economics and Finance La Trobe University Victoria 3086 Australia, Phone: (+61 3)9479 5701 Fax: (+61 3)9479 1654 (fax) E-mail: r.waschik@latrobe.edu.au (๖2006-Center for International Economics, Sejong Institution, All Rights Reserved.
} 
exist within a country debating the virtues of free or freer trade, there is the theoretical question of whether regional coalitions will eventually evolve into a global coalition, or whether regionalcoalitions eectively block further expansion.Consider a worldwithmany trading nations where the rst-bestor economicallyecientsolution is to have undistortedtrade between all nations. Beginning from an initial equilibrium where trade between nations is distorted, suppose some subset of nations forms a PTA, liberalizing trade between members of the PTA while maintaining distorted trade between members of the PTA and non-members. The primary concern of this paper is the following question: Would allowing PTAs to exist and expand ultimately lead to an equilibrium with global free trade, or might competing PTAs block attainment of this grand coalition?

A considerable literature has developed which considers this problem from a number of dierent points ofview, usinga number of dierentmodeling tools. This literature can usefully be divided into three groups: (i) theoretical models of international trade, often concentrating on the trade-creating and trade-diverting aspects of preferential trade agreements; (ii) numerical models looking at the eects of particular preferential trade agreements; (iii) game-theoretic models of coalition formation. A thorough survey of manytheoreticaltreatments ofthe implications of PTA formation is given in Panagariya (2000). A survey of the 'building blocks vs. stumbling blocks' literature is provided in Section 7 of Panagariya (2000) and Section 2.2 of Adams et al (2003).

In evaluating whether PTAs are welfare-improving or welfare reducing, theoretical trade models often use the notions of trade creation and trade diversion described in Viner (1950). ${ }^{1}$ As such, a PTA will be welfare-improving as the reductions in tariffs on trade between PTA-members increase trade. However, given existing tariffs on nonmember trade, these tariff reductions imply greater discrimination on non-member trade, leading to a potential diversion of trade from a lower-cost nonmember supplier. Kemp and Wan (1976) show that in a customs union (CU) where members set a common external tariff (CET) on non-member trade, the CET can always be adjusted in such a way so as to keep constant trade between the $\mathrm{CU}$ and non-members, thereby eliminating trade diversion and ensuring that expansion of a CU leads only to trade creation ${ }^{2}$. In this setting, expansion of a CU can ultimately

\footnotetext{
${ }^{1}$ As noted in Panagariya (2000), Kowalczyk (1990) suggests decomposing the eects of $\mathrm{PTA}^{\circ} Ø$ s into terms-of-trade and volume-of-trade eects. Harrison etal(1993) provide an alternative welfare decomposition ofthe formation of CUs. Nevertheless, mostofthe literature evaluates PTA's in terms oftrade creation and trade diversion.
} 
lead to an equilibrium where all regions are members of a single CU: global free trade.

More recently, using a trade model with monopolistic competition, Krugman (1991) describes a setting in which world welfare is minimized with three trading blocs. Bond and Syropoulos (1996) extends Krugman (1991) to show that the relationship between bloc size andexternal tariff is ambiguous. Bhagwatiand Panagariya (1996) conclude that PTAs are overall welfare-reducing, owing to the substantial amount of trade diversion which they engender. Yi (1996) argues that CUs are stepping-stones to global free trade under 'open regionalism' but are stumbling blocks under 'unanimous regionalism'. Zissimos and Vines (2000) show that even PTAs which are consistent with the World Trade Organization's Art.XXIV present a barrier to achievement of multilateral free trade. Bhagwati (1992) suggests that trade diversion can be reduced by ruling out FTAs where members maintain separate tariffs on non-member trade, andonlyallowing CUs.

On the other side, some argue that PTAs may enhance the pursuit of multilateral trade liberalization. Campa and Sorenson (1996), for example, argue that regional trading blocs permit small countries to undermine the market power of larger trading economies, in a model where all produced goods are imperfect substitutes. Richardson (1993) argues that small countries have a greater incentive to reduce protection when joining in a FTA with larger countries, particularly since they are not bound to adopt a partner's tariff on trade with non-member countries. The elimination of protection on trade with other FTA members leads to further endogenous reduction in protection on non-member trade.

Politicaleconomyaspects of PTAs have been incorporated in Grossman and Helpman (1995)and Krishna (1998)who argue that FTAs are more likely to be accepted if theyare predominately trade diverting rather than trade creating. Bagwell and Staiger (1998) argue that FTAs and possibly CUs conict with the GATT principles of reciprocity and non-discrimination, thereby posing a threat to the multilateral trading system. Levy (1997) uses a median-voter model to show how FTAs can undermine support for multilateral trade liberalization, if the welfare of an FTA member is raised above the level achievable through multilateral free trade. Andriamananjara (2002) uses a multi-country politicaleconomymodel to show that progressively larger trading blocs are likely to block admission of a non-member, thereby blocking attainment of global free trade, unless blocs set suciently low

\footnotetext{
${ }^{2}$ This result had been extended in a number of dimensions.See Panagariya and Krishna (1997), the papers collected in Kemp (2001) and the references therein.
} 
tariffs on non-members.

This theoretical literature identies two important aspects of PTAs. How members of a CU set their CET on non-member trade is extremely important in aecting results. A higher CET implies greater trade diversion. And the relative size of countries joining a PTA is very important in aecting both the extent to which a country is better off joininga PTA, andthe extent to whichnon-members are worse off after a PTA is formed. Common to bothofthese issues is the notion thata larger PTAessentially presents nonmembers with a larger trading bloc which has greater monopoly power in international trade. Even given the trade-creating benets of tariff reductions within a PTA, greater monopoly power of a larger PTA means further benets due to positive terms-of-trade eects, necessarily implying negative terms-of-trade effects for non-members.

In the literature which looks at how members of a PTA set tariffs against nonmembers, Gatsios and Karp (1995), Syropoulos (2002), and Melatos and Woodland (2003) focus on how CUs choose their CET, and highlight the potential for delegation within the CUto raise welfare. In a modelwhere external tariffs are determine dendo-genously through lobbying, Panagariya and Findlay (1996) show how trade liberaliza-tion through PTA's leads to increased protection against non-members. Cadot, de Melo and Olarreaga (1999) show that deeper integration can leadto rising protection againstnonmembers, and suggest that FTAs are likely to welfaredominate CUs. There is some evidence (see Panagariya (1999) and Hindley and Messerlin (1993), for example) that PTA members raise barriers on trade with nonmembers after the formation of a PTA.

In much of the theoretical literature cited above, PTA members are assumed to set optimal tarffis on trade withnon-members. Markusen and Wigle (1989)solved for Nash equilibrium tariffs between Canada andthe U.S. usinga Numerical General Equilibrium (NGE) model with eight trading blocs each producing and trading six goods. Due to computational constraints, they assumed that Canada and the U.S. maintained the same tariff mix, so that tariffs were all scaled up or down together, and the behaviour of other trading regions was held constant. They considered the eects of country size, scale economies, and capital mobility, and showed that in their model, smaller country size, the presence of increasing returns to scale in production of manufactured goods and the presence of capital mobility all contributed to smaller optimal tariffs. ${ }^{3}$ More recently, Perroni and Whalley

\footnotetext{
${ }^{3}$ The Nash equilibrium tariff rates for Canada and the U.S. in Markusen and Wigle (1989) were $6 \%$ and $18 \%$, respectively.
} 
(2000) have considered the outcomes of various Nash equilibrium tariff games in a NGE model with six regions. While coalition structure was exogenous, a number of dierent coalitions were considered, including FTAs and CUs between dierent groups of regions. CUs were typically preferred by member countries due to the implicit increase in market power of the coalition, andsmallregions benetted from coalition membership due to the insurance that membership aords them against the threat of retaliation.

An important failing of this literature is that the structure of any PTA is specied exogenously. Kennan and Riezman (1990) suggest a novel way to attack this problem. Using a three-country model they examine the welfare implications of various forms of coalition structure. In particular, Kennan and Riezman consider three structures: an FTA between two of the countries, a CU between two of the countries, and free trade between all three countries (global free trade). Countries are then free to choose which of all possible coalitions to join to make themselves as well of as possible, thereby endogenizing the coalition formation process. The results show that a country may be better-off in a CU than with global free trade. In a subsequent paper, Riezman (1999) nds that banning bilateral trade agreements may result in more, not less, protection. In each of these papers, an important factor in determining whether a preferential trading agreement like a CUor an FTAcan workas a stepping-stone towards Global Free Trade is the relative size ofregions forminga particular trade bloc. This factor is also important in determining which trading blocs ultimately form when membership of trading blocs is determined endogenously.

The approach pioneered by Kennan and Riezman has a couple of drawbacks. First, the Kennan-Riezman models are based on pure exchange economies, ruling out any eciency eects from the production sector arising from the impact of coalition formation on resource allocation. Second, the Kennan-Riezman models are completely abstract and have no connection to trade data. This is signicant given that many of the arguments for and against regional trading blocs are based on their actual eects on trade ows and trade diversion.

The present paper addresses the shortcomings of the Kennan-Riezman models, and builds on the earlier work by Markusen and Wigle (1989)and Perroniand Whalley (2000) by endogenizing the coalition-formation process between regions. The present paper is also related to the modular approach to coalition formation proposed in Burbidge et al. (1997) in which states may choose to form coalitions to capture eciency gains from tax coordination. In their paper, joining a coalition 
entails setting a common (Nash equilibrium) tax to maximize the coalition's aggregate pay off and committing to a transfer scheme to share the gains. In our paper, coalitions maximize a common (Nash equilibrium) tariff against nonmembers with no sharing (side payments) of the resulting gains. While sharing the gains is not an option for coalitions, we consider severalalternative mechanisms bywhicha coalition maychoose its CET. Also, Burbidge et al. (1997) use the conceptofa coalition-proof Nashequilibrium to determine coalition structure, whereas we use the core to determine coalition structure.Andwhile Burbidge etal.(1997) use numerical examples to illustrate their results, we use an NGE model with actual production, consumption, and trade data.

Of course, there exist mechanisms which constrain the way that nations set their tariffs. Members ofthe World Trade Organization bindtheir tariffs accordingto Article IIofthe General Agreement on Tariffs and Trade, and Article XXI Vconstrains the way thatmembers of PTA's can set their tariffs on trade withnon-members. To highlight the potentialrole ofthese Articles, we consider a separate setofsimulations whichconstrain the way that PTA members and non-members set their tariffs after a PTA is formed.

Specically, we examine a general equilibrium model of production and trade that is benchmarked to a 1995 world trading equilibrium in which 5 regions produce and trade 12 goods. The model and the data are described in Section 2. Methodological issues are discussed in Section 3 where we describe three dierent mechanisms by which CUs set their CET. We then investigate the welfare implications of CUs, FTAs, and global free trade, and, using Riezman ${ }^{\circ} Ø$ s (1999) notion of blockingcoalitions, determine which coalition of trading blocs will form endogenously in a Nash tariff-setting game. Results from this coalition-formation game are presented and discussed in Section 4. We show that CUs tend to dominate the coreof the game, and are typically more distortionary than FTAs, involving larger welfare gains for coalition members and larger welfare losses for non-members. Section 5 contains some concluding remarks.

\section{General Equilibrium Model}

This section describes the general equilibrium model and Benchmark Equilibrium Data Set (BEDS). The model has five regions: North America (NA), South America (SA), the European Union (EU), Asia and Australia (ASIA), and an aggregate region comprising the rest of the world (ROW). The regional 
disaggregation is displayed in Table 1, so that the set of all regions is:

$$
\text { REGS }=\{N A, S A, E U, A S I A, \text { ROW }\} .
$$

Table 1 also reports total income in each region in the initial data set, to give an idea of the relative size of each region. In each region, final goods are produced using three primary inputsland, labour, and capitaland intermediate inputs. ${ }^{4}$ The production side of the economy is disaggregated so that twelve final goods are produced. Each region produces, imports and exports all twelve goods, so there is cross-hauling in all goods. Trade is accommodated using the so-called Armington assumption, so that the same goods produced in different regions are imperfect substitutes for one another. The commodity disaggregation is displayed in Table 2, so that the set of all commodities is:

GOODS $=\{$ AGR, FFM, FOO, TEX, PPP, CRP, MET, TRN, MAN, UTI, T\&T,

Table 1. Regional Aggregation for Benchmarked Equilibrium Data Set, 1995

\begin{tabular}{|c|c|c|c|c|c|}
\hline & $\overline{\mathrm{NA}}$ & SA & EU & ASIA & ROW \\
\hline & Canad & aCentral America & UK & Australia & EFTA \\
\hline & USA & Caribbean & Germany & New Zealand & $\begin{array}{l}\text { Central European } \\
\text { Associates }\end{array}$ \\
\hline & Mexic & oVenezuela & Denmark & Japan & Former Soviet Union \\
\hline & & Colombia & Sweden & Korea & Turkey \\
\hline & & Rest of Andean Pact & Finland & Indonesia & Rest of Middle East \\
\hline & & Argentina & Rest of EU & Malaysia & Morocco \\
\hline & & Brazil & & Philippines & Rest of North Africa \\
\hline & & Chile & & Singapore & $\begin{array}{l}\text { South African Customs } \\
\text { Union }\end{array}$ \\
\hline & & Uruguay & & Thailand & $\begin{array}{l}\text { Rest of Southern } \\
\text { Africa }\end{array}$ \\
\hline & & Rest of South America & & Viet Nam & $\begin{array}{l}\text { Rest of sub-Saharan } \\
\text { Africa }\end{array}$ \\
\hline & & & & China & Rest of World \\
\hline & & & & Hong Kong & \\
\hline & & & & Taiwan & \\
\hline & & & & India & \\
\hline & & & & Sri Lanka & \\
\hline & & & & Rest of South Asia & \\
\hline Share of & & & & & \\
\hline $\begin{array}{l}\text { World } \\
\text { Income }\end{array}$ & 0.282 & 0.049 & 0.290 & 0.286 & 0.094 \\
\hline
\end{tabular}

\footnotetext{
${ }^{4}$ The primary factor land is used only in the production of agriculture.
} 
Table 2. Industry Aggregation for Benchmarked General Equilibrium Data Set, 1995

\begin{tabular}{lcccccccc}
\hline \multicolumn{1}{c}{ Description } & $\begin{array}{c}\text { Canadian } \\
\text { SIC Codes }\end{array}$ & $\begin{array}{c}\text { Industry's Share of } \\
\text { Total Value Added } \\
\text { in World (Percent) }\end{array}$ & \multicolumn{4}{c}{$\begin{array}{c}\text { Exports as a Share } \\
\text { of Total Domestic } \\
\text { Production (Percent) }\end{array}$} \\
\hline Agriculture & 01,02 & 3.6 & 14.8 & 11.7 & 16.6 & 4.3 & 8.0 \\
Forestry, Fishing, Mining & $03-09$ & 2.0 & 13.8 & 30.7 & 26.1 & 14.5 & 45.4 \\
Food Processing & $10-12$ & 6.0 & 5.8 & 10.0 & 17.5 & 5.7 & 8.3 \\
Textiles & $17-19,24$ & 2.4 & 9.2 & 10.4 & 37.3 & 29.3 & 24.0 \\
Pulp and Paper & $25-28$ & 3.4 & 12.1 & 10.0 & 21.1 & 6.9 & 14.3 \\
Chemicals and Rening & $15,16,36-37$ & 5.8 & 13.3 & 10.0 & 33.0 & 11.2 & 18.7 \\
Minerals, Metals, Metal & $29-31,35$ & 5.4 & 9.2 & 11.5 & 22.0 & 9.0 & 23.5 \\
Products & & & & & & & & \\
Transportation Equipment & 32 & 2.9 & 20.5 & 9.4 & 40.0 & 28.1 & 14.1 \\
Other Manufacturing & 33,39 & 5.9 & 30.0 & 8.2 & 45.0 & 34.0 & 30.0 \\
Utilities and Construction & $40-44$ & 11.6 & 0.1 & 0.0 & 1.4 & 0.1 & 1.4 \\
Trade and Transportation & $45-69$ & 17.3 & 5.1 & 6.6 & 10.5 & 7.7 & 14.4 \\
Government and Private & $70-77,81-86$, & 33.7 & 2.3 & 2.2 & 3.5 & 1.9 & 3.7 \\
Services & $91-92,96-99$ & & & & & & \\
\hline
\end{tabular}

SER $\}$.

Table 2 also reports total world output of each good as a share of total world output, as well as exports as a share of domestic production by region for each good. These latter columns give an indication of the importance of trade in any one commodity for each region. As is evident, the data set reports very little trade in services, though the three service sectors (UTI, T\&T, SER) account for over 60 per cent of total world output. As such, we would expect the welfare effects of changes in tariffs on merchandise trade (the first 9 goods) to be relatively small.

The final consumption goods in any region are consumed by a representative consumer in each region, who owns all primary factors of production, and supplies all land, labour and capital to the production sector. All primary factors are completely mobile within a region but immobile between regions. There are a number of distortions in the initial equilibrium data set, including production taxes, export taxes and import taxes. The data set is an aggregated version of version 4 of the GTAP data set described in Hertel (1995), which describes a world trading equilibrium in the year 1995 .

For each sector $j \in$ GOODS, finished goods $\left(y_{i}\right)$ are produced using intermediate inputs from sector $j \in \operatorname{GOODS}\left(x_{i j}\right)$ and primary inputs: Land $\left(H_{i}\right)$, labour $\left(L_{i}\right)$, and capital $\left(K_{i}\right)$. As is typical in such NGE models, we assume that production 
technology displays constant returns to scale, and is represented by nested CES production functions of the form:

$$
y_{i}=\left[\sum_{j \in G O O D S} \delta_{j} x_{i j}^{\frac{\gamma_{i}-1}{\gamma_{i}}}+\delta_{V} V_{i}^{\frac{\gamma_{i}-1}{\gamma_{i}}}\right]^{\frac{\gamma_{i}}{\gamma_{i}-1}}
$$

where $V_{i}=\left[\alpha_{H} H_{i}^{\frac{\rho_{i}-1}{\rho_{i}}}+\alpha_{L} L_{i}{ }^{\frac{\rho_{i}-1}{\rho_{i}}}+\alpha_{K} K_{i}^{\frac{\rho_{i}-1}{\rho_{i}}}\right]^{\frac{\rho_{i}}{\rho_{i}-1}}, \quad \forall i \in$ GOODS

where $x_{i j}$ is the amount of good $j$ used in production of good $i$. The substitution elasticity between primary inputs, $\rho_{i}$, is given in Table 3 . Intermediate inputs xij and the aggregate value-added $V_{i}$ are combined using fixed-coefficients production technology, so $\gamma_{i} \rightarrow 0 \forall i$. The structure of production is shown in Figure 1. All markets are assumed to be perfectly competitive, with free entry and exit of firms, so economic profits are equal to zero in all industries in equilibrium. Producers take all output and input prices as given, and these are all normalized to unity in the initial equilibrium

The demand side of each economy is represented by a system of demand

Table 3. Independent Primary Input Substitution and Trade Elasticities

\begin{tabular}{lccc}
\hline \multicolumn{1}{c}{ Industry } & $\begin{array}{c}\text { Primary Input } \\
\text { Substitution Elasticity }\end{array}$ & $\begin{array}{c}\text { Domestic/Import } \\
\text { Substitution Elasticity }\end{array}$ & $\begin{array}{c}\text { Trade } \\
\text { Elasticity }\end{array}$ \\
\hline Agriculture & $\rho_{i}$ & $v_{i}$ & $\tau_{i}$ \\
Forestry, Fishing, Mining & 0.40 & 2.2 & 4.4 \\
Food Processing & 0.60 & 2.1 & 4.2 \\
Textiles & 0.80 & 2.2 & 4.4 \\
Pulp and Paper & 0.90 & 2.2 & 4.4 \\
Chemicals and Rening & 0.80 & 1.7 & 3.4 \\
Minerals, Metals, Metal Products & 0.90 & 1.9 & 3.8 \\
Transportation Equipment & 0.90 & 2.1 & 4.2 \\
Other Manufacturing & 0.80 & 3.0 & 6.0 \\
Utilities and Construction & 0.90 & 2.1 & 4.2 \\
Trade and Transportation & 1.00 & 2.0 & 4.0 \\
Government and Private Services & 1.20 & 2.0 & 4.0 \\
\hline
\end{tabular}


Figure 1. Structure of Production of Output

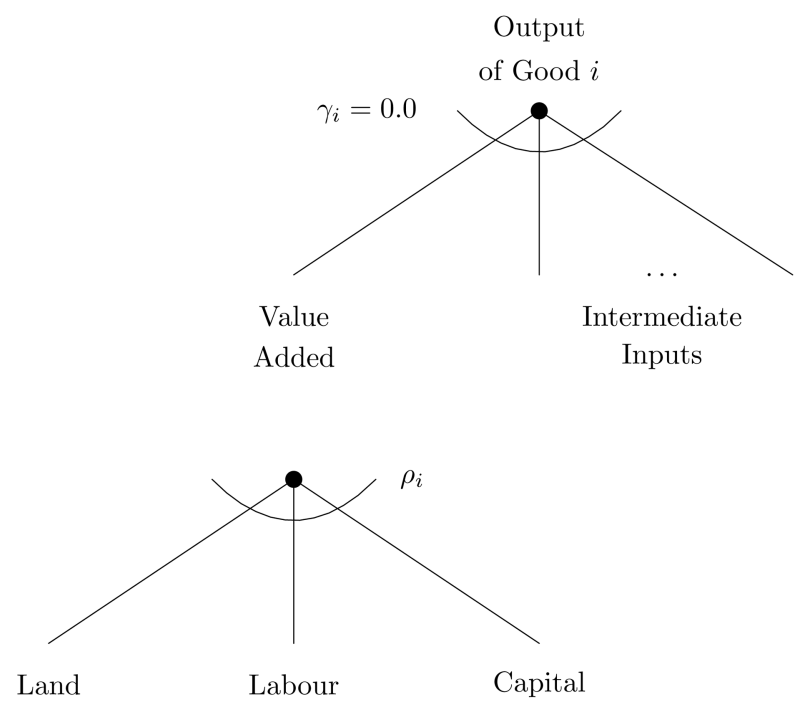

functions derived from the solution to the representative consumerÅfs utility maximization problem when utility for the representative consumer in region $r$ is represented by a Linear Expenditure System of the form:

$$
U^{T}=\Pi_{i=0}^{n}\left(z_{i}^{r}-\bar{z}_{i}^{r}\right)^{\theta_{i}^{r}} \forall r \in R E G S, \quad i \in\{G O O D S\},
$$

where $z_{i}^{r}$ is the consumption of good $i$ and $\bar{z}_{i}^{r}$ is the subsistence consumption of good $i$ by the representative consumer in region $r$. As an example, the structure of consumption of agriculture in North America is described in detail in Figure 2, with a corresponding description of the structure of consumption goods applying for all goods in all regions.

The LES is used to represent preferences since it allows different income elasticities of demand for different commodities. This allows for greater flexibility in benchmarking the initial data set than the Cobb-Douglas or CES utility function, which would restrict all income elasticities to unity. The income elasticities for all consumption goods $i \in\{$ GOODS $\}$ are based upon those used in Jomini et al. (1994).

Of total output of industry $i$ in region $r$, some amount is exported, and the remainder is consumed within region $r$. Trade must be balanced, so exports of good $i$ by region $\mathrm{r}$ must equal imports of good $i$ by all other regions. Trade in any region 
Figure 2. Structure of Consumption in the BEDS

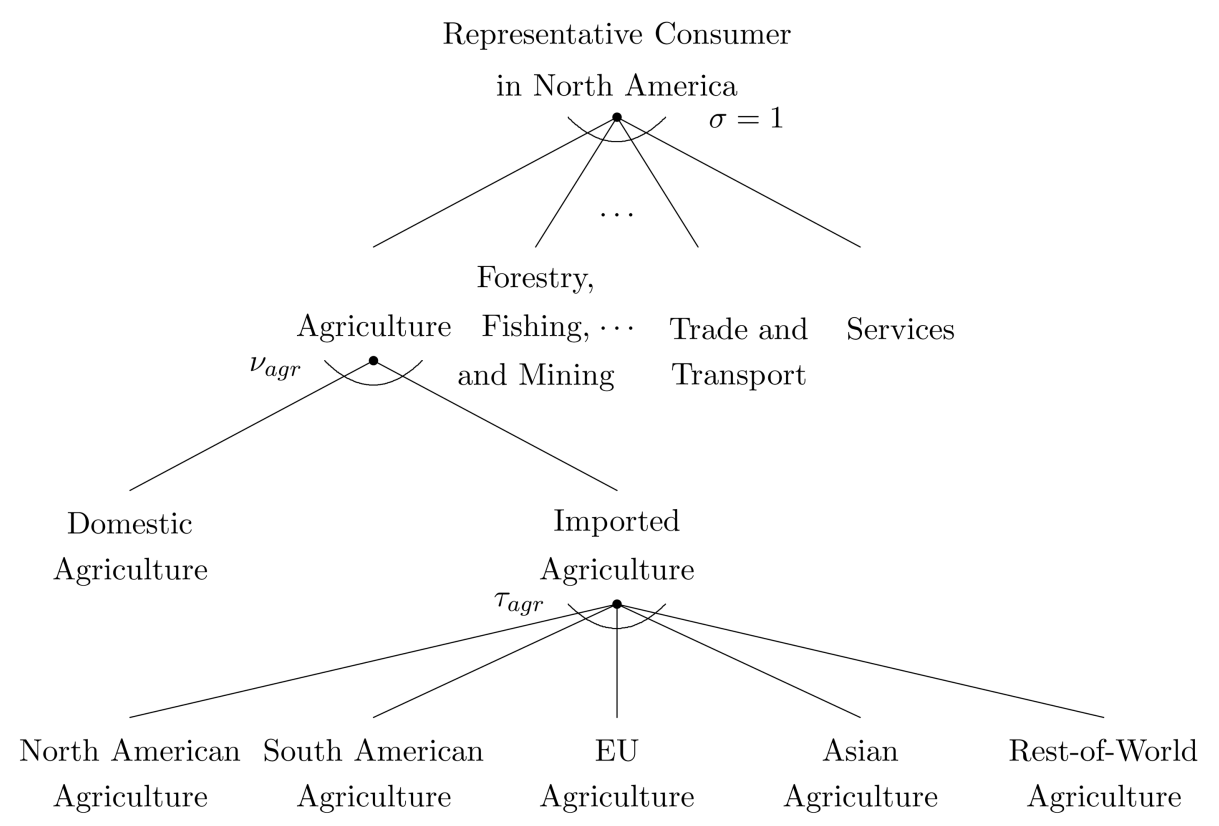

can be distorted by the presence of export taxes/subsidies and import taxes. Trade taxes in the initial equilibrium are available from the authors on request. Import taxes are a combination of tariffs and tariff-equivalents of quantity restric-tions on imports.

The nesting structure of traded goods is illustrated in Figure 2. The final good $i$ in region $r$ is a nested CES aggregate of the domestically produced good $\mathrm{i}$ and imported good $i$, which itself is a CES aggregate of imports of good $i$ from different regions. The substitution elasticity between goods imported from different regions (the lowest nest in Figure 2) is $\tau_{i}$, reported in Table 3 . The aggregate imported good is combined with the domestically produced good with a substitution elasticity given by $v_{i}$, reported in Table $3 .{ }^{5}$ In setting the import substitution elasticities $\tau_{i}$, we adopt the method used in Jomini et al. (1994:81) and set $\tau_{i}=2 \times$ $v_{i}$. These trade elasticities are of crucial importance to the results which follow, since regions will be charging optimal tariffs in the simulations described in Section $3 .{ }^{6}$ To show how sensitive results are to specification of these elasticities,

${ }^{5}$ The central case values for the elasticity of substitution between domestic and aggregate imported goods $v_{i}$ are derived from those reported in Table 3.5 of Jomini et al. (1994:77). 
we report sensitivity analysis results in Section 4.6 below by repeating experiments for low $\left(v_{i}^{l o}=0.5 \times v_{i}\right)$ and high $\left(v_{i}^{h i}=2 \times v_{i}\right)$ values for these independently specified parameters.

\section{Modeling the Formation of PTAs}

The starting point for all our experiments is the initial BEDS. Compared to this initial equilibrium, we consider the following types of trading arrangements.

- Nash Equilibrium (Nash): Each region sets optimal tariffs on trade with all other regions, given that all other regions are also charging optimal tariffs.

- Free Trade Areas (FTA): Two or more regions reduce their tariffs on each other's imports to zero while individually setting tariffs on imports from other regions.

- Customs Unions (CU): Two or more regions reduce their tariffs on each other's imports to zero while charging a CET on imports from other regions.

- Global Free Trade (GFT): All countries reduce their tariffs to zero.

Since there exist non-tariff distortions (production and export taxes) in the initial BEDS, some regions could experience a decrease in welfare due to a removal of all import tariffs. Because we consider our results in the context of a literature where GFT is a first-best equilibrium, having GFT as a second-best equilibrium is undesirable. Thus, in all simulations for all types of trading arrangements, non-tariff distortions are removed and GFT is the first-best equilibrium. In addition, tariffs on the majority of traded services in the initial BEDS are zero, and no region has tariffs on traded services of greater than $2 \%$. Traded (non-transport) services in the BEDS are very small, never accounting for more than $4 \%$ of domestic production. For these reasons, tariffs on traded services in all regions are set to zero in all simulations, so that regions set optimal tariffs only on agricultural, forestry-fishing-mining, and processed and manufactured goods.

The model is solved as a two-stage game. In the second stage, regions take the structure of any PTA(s) as given, and set tariffs on trade with all trading partners. This second-stage problem is solved for all potential PTAs which can form. Then in the first stage, regions choose which PTA they will join, given the utility

${ }^{6}$ For example, see Markusen et al. (1995:256), for a description of how optimal tariffs depend upon trade elasticities. While some NGE modellers regard the trade elasticities used in the Salter model as being on the high side, we consider them more appropriate for these simulations since smaller trade elasticities would over-state each region's market power in world output markets, resulting in optimal tariffs which would be unrealistically high. 
difference between any trading arrangement and the initial BEDS. In evaluating which coalition to join, side payments are ruled out completely.

The most important factor affecting results is the mechanism by which regions set tariffs. Of course, under GFT, all regions set tariffs to zero, while under Nash, any region sets optimal tariffs on imports from all other regions, maximizing its own welfare, taking the tariffs charged by other regions as given. We need to specify the tariff-setting behaviour of regions when PTAs are allowed to form. Regions will either:

- not be a member of any PTA,

- be a member of a CU, or

- be a member of an FTA.

We presume that regions which are not members of any PTA always charge optimal tariffs on imports from all other regions. Membership in a CU or an FTA essentially constrains the tariff matrix of each member. The key difference between FTAs and CUs is that the external tariffs are set independently under an FTA, whereas they are set jointly under a CU. ${ }^{7}$ As Kennan and Riezman (1990) observe, a CU internalizes a tariff externality between member countries if the countries import the same good. As one region increases its tariff, the terms of trade improve for all member countries. The Common External Tariff (CET) takes this externality into account in determining the optimal tariff. There is a complication with CUs, however: There is a conflict of interest between member countries on the level of the CET. Thus, an important issue in the formation of a Customs Union is how the CET is set, for as we will see in Section 4, results are sensitive to the way in which a CU chooses its CET. We consider four different mechanisms by which PTAs choose tariffs on non-member trade:

Mechanism 1: FTA members charge optimal tariffs on non-member trade, while CU members charge a CET on non-member trade which maximizes the weighted sum of changes in income of CU members, where the weights are the share of each regionÅfs income in the total income of the CU.

This mechanism is simple and intuitively appealing, and has been used in the

\footnotetext{
${ }^{7}$ The FTA assumes that rules of origin (ROOs) are strictly and costlessly enforced so that different tariffs between member countries can exist. Of course, such ROOs are themselves potentially distortionary, as shown by Krueger (1997) who argues that CUs are pareto-superior to FTAs and that FTAs will lead to more opposition to further multilateral trade liberalization.
} 
literature on PTA formation to specify how CU members set a CET on nonmember trade (see Perroni and Whalley (2000), for example). But as is the case in many other examples of CET choice, ${ }^{8}$ this mechanism is not necessarily consistent with maximizing behaviour on the part of individual CU members, since any individual region's membership within a trading bloc will be motivated by changes in income within that individual region. For example, if members of a particular trading bloc are of different sizes, one region might prefer a higher CET while another might prefer a lower CET. Without side payments, it is difficult to motivate a region's agreement to a CET that leaves it worse off.

To address this concern, we consider the following mechanism by which CUs set their CET:

Mechanism 2: FTA members charge optimal tariffs on non-member trade, while CU members increase the CET on non-member trade from a low level until no CU member can be made better-off without making another member worse-off.

Under this mechanism, no CU member suffers a decrease in utility when the CET is adjusted to its chosen level. To illustrate how this is done, suppose NA and SA form a CU, and consider how they set their CET on AGR imports from EU. The members of the CU choose a starting level for the CET equal to the level of the tariff of the member region with the lowest initial tariff in the BEDS. The tariff is then increased incrementally in steps of 1 per cent. Following each step, if both NA and SA are better off, the tariff is increased until either NA or SA is made worse off. If either NA or SA is made worse off, the tariff is decreased until neither NA nor SA are worse off. In this way, the CET is chosen to be individually rational for all members of the CU. ${ }^{9}$ However, since we do not allow side payments, this mechanism leaves some gains from further changes in the CET unexploited. ${ }^{10}$ For

\footnotetext{
${ }^{8}$ For example, Riezman (1999) assumes that regions choose the CET which gives members the average of utility which would obtain when each chooses the CET unilaterally. Riezman (1985) assumes that $a$ dominant CU member sets the CET. Others (Krugman (1991), Bond and Syropoulos (1996), for example) have symmetric regions in the $\mathrm{CU}$, so there is no scope for conflict over choice of the CET. Gatsios and Karp (1995), Syropoulos (2002), Melatos and Woodland (2003) and others consider delegation in CUs to determine the CET.

${ }^{9}$ This mechanism is equivalent to having one region delegate setting of the CET to the other so that no region is worse off. For a thorough discussion of pareto optimal delegation of CET setting in a CU, see Melatos and Woodland (2003).
} 
example, suppose Mechanism 2 implies that NA and SA would set a tariff of $t_{\text {agree }}$ on imports of AGR from the EU. The marginal welfare effect of a change in this tariff will be zero for one of the two regions (NA, for example), but strictly positive for SA, so SA could make a side-payment to NA leaving both regions better off from an increase in the tariff beyond $t_{\text {agreu }}$. For this reason, we refer to the Mechanism 2 CET as locally Pareto efficient.

Many authors have argued that the ability to exert monopoly power in setting tariffs is a key reason why PTAs present stumbling blocks, ultimately blocking attainment of global free trade. There is some empirical evidence that members of some PTAÅfs have raised tariffs against trade with non-members (summarized in Panagariya (1999:499)). To limit the negative trade diverting effects of such increases in external tariffs, Bhagwati (1992) argues that FTAs should be banned, and CUs should be disciplined in how they set their CET on non-member trade. On the other hand, Richardson (1993) argues that PTA members can have an incentive to lower tariffs on non-member trade after a PTA is formed. Of course, contracting parties to the World Trade Organization agree under GATT Art.II to bind their tariffs, and GATT Art.XXIV disciplines the way that PTAs set tariffs on non-member trade. ${ }^{11}$

How PTA members set their external tariffs will certainly have important implications for the outcome of the coalition formation game. So to contrast our results when regions set optimal tariffs as described in Mechanisms 1 and 2, we consider the following alternative mechanisms:

Mechanism 3: FTA members charge optimal tariffs on non-member trade, while CU members set the CET on non-member trade at the level of the tariff charged by the CU member with the lowest initial tariff

Mechanism 3 allows us to operationalize the rule proposed by Bhagwati (1992:455) that CUs should be allowed while FTAs should be banned in order to minimize trade diversion. ${ }^{12}$ It should be clear that this mechanism imposes a

\footnotetext{
${ }^{10}$ Perroni and Whalley (2000) and Burbidge et al. (1997) allow side payments between coalition members. However, in the present setting, side payments can only be implemented by adding (arbitrary) assumptions about the distribution of gains in the $\mathrm{CU}$ between members. Moreover, we argue in Section 4.2 that incorporating side payments would not affect whether CUs block GFT when CUs choose their CET according to Mechanism 2.

${ }^{11}$ A survey of the effects of PTAs on external tariffs is given in section 3(c) of Panagariya (1999:495-500).
} 
considerable amount of discipline on any $\mathrm{CU}$. As regions join to form a $\mathrm{CU}$, they present non-members with a larger single region to trade with, effectively increasing the potential market power which the CU could use to affect world terms-of-trade in its favour by increasing its CET. Mechanism 3 effectively commits regions which form a $\mathrm{CU}$ not to use any of this market power to their own benefit.

A growing literature considers the role of Art.XXIV of the GATT in affecting the behaviour of PTAs. For example, Zissimos and Vines (2000) argue that Art. XXIV un-dermines the multilateral liberalization process, and McMillan (1993) suggests that it should focus on trade volumes between PTA members and nonmembers, rather than tariffs, while Snape (1993:285) suggests that Art.XXIV does still appear to have a restraining influence on PTAs. To see how application of Art.XXIV might affect our results, we consider:

Mechanism 4: FTA members maintain tariffs on non-member trade at preFTA levels, while CU members set the CET at the average level of tariffs charged by $\mathrm{CU}$ members prior to union.

As stated, Mechanism 4 implies a strict interpretation and application of Art. XXIV of GATT 1994, which states:

... the provisions of this Agreement shall not prevent the formation of a customs union provided that the duties shall not on the whole be higher than the general incidence of the duties prior to the formation of such union. ${ }^{13}$

A subsequent document issued by the WTO explains that assessment of the incidence of duties prior to formation is to be based on average tariff rates. ${ }^{14}$ Clearly, Mechanism 4 restrains regions which form either a CU or an FTA from using any market power to their own benefit. Of course, there has been considerable debate over the effectiveness of Art.XXIV in practice, highlighted by the fact that so many GATT Working Parties established to examine compatibility

\footnotetext{
${ }^{12}$ In general, Mechanism 3 on its own only disciplines CUs. But in Section 4.3 below, we consider Mechanism 3 on its own, and also look at the outcome of the coalition formation game when CUs are banned and when FTAs are banned. It is this latter experiment (Mechanism 3 and FTAs are banned) which operationalizes Bhaghwati (1992:455).

${ }^{13}$ Article XXIV, paragraph 5; some text has been removed for clarity.

14“"Understanding on the Interpretation of Article XXIV of the General Agreement on Tariffs and Trade 1994."
} 
of PTAs with the GATT in the past did not reach any definitive conclusions (see McMillan (1993:298), Snape (1993:285), and the references therein). It should be stressed that Mechanism 4 implies a very strict application of Art.XXIV.

In all mechanisms thus far, we assume that regions which do not belong to any PTA charge optimal tariffs on imports from other regions. This assumption could be challenged on the grounds that WTO membership implies restrictions even on the be-haviour of non-PTA members, since contracting parties to the WTO bind their tariffs under Art.II. ${ }^{15}$ To accommodate this concern, we consider the following variant to Mechanism 4:

Mechanism 4a: Same as Mechanism 4, except regions which do not belong to any PTA also have tariffs bound at pre-PTA (i.e., BEDS) levels.

As was the case with Mechanism 4 above, Mechanism 4a implies a very strict interpretation and application of Art.II, and presumes the tariff bindings in Art.II do actually bind. Table 4 summarizes the five tariff mechanisms.

There are 5 regions in the model implying a total of 152 possible coalitions for each mechanism. The Nash equilibrium and global free trade account for two of the possible configurations. In the case of FTAs, there are 10 purely bilateral coalitions (i.e., two regions forming a bloc and the other regions remaining independent), 10 purely trilateral coalitions (i.e., three regions forming a bloc), and 5 purely quadrilateral (four-region) coalitions that could form from the 5 regions. There are also 15 coalitions comprising bilateral FTAs (i.e., two blocs of two

Table 4. Description of Tariff Setting Mechanisms for PTAs

\begin{tabular}{clrl}
\hline Mechanism & \multicolumn{1}{c}{ CUs } & \multicolumn{1}{c}{ FTAs } & \multicolumn{1}{c}{ non-members } \\
\hline 1 & $\begin{array}{l}\text { maximize weighted sum of } \\
\text { income changes }\end{array}$ & individually optimal & individually optimal \\
2 & locally Pareto ecient & individually optimal & individually optimal \\
3 & lowest of BEDS level (Bhagwati rule) & individually optimal & individually optimal \\
4 & $\begin{array}{l}\text { average of BEDS level (GATT } \\
\text { Art.XXIV) }\end{array}$ & fixed at BEDS level & individually optimal \\
$4 a$ & $\begin{array}{l}\text { average of BEDS level (GATT } \\
\text { Art.XXIV and Art.II) }\end{array}$ & fixed at BEDS level & fixed at BEDS level \\
\hline
\end{tabular}

\footnotetext{
${ }^{15}$ As noted in Panagariya (1999), many countries have tariffs at levels which are below GATT bindings, implying that there is scope for tariffs to be raised. Even for countries where tariffs are at bound levels, protection could be increased through the use of anti-dumping measures. But Nash tariffs in our tariffsetting game are likely to be much higher than WTO bound tariffs. For example, Nash tariffs in Perroni and Whalley (2000) are generally much larger than $100 \%$.
} 
regions each) and 10 coalitions of bilateral-trilateral FTAs (i.e., one bloc of two regions and another bloc of three regions) that could form. Thus, there are 50 total possible coalitions of FTAs. Similarly, there are 50 possible coalitions of CUs. In addition, there are 50 possible configurations with two blocs where one is an FTA and the other is a CU. Together with the Nash equilibrium and global free trade coalitions, there are thus 152 coalitions for each mechanism.

In order to determine which coalition will ultimately obtain, we need a device to compare one coalition with another. A natural choice is the notion of blocking coalitions and the core solution concept used by Kennan and Riezman (1990) and Riezman (1999). Thus, consider a coalition made up of a subset $\mathrm{S}$ of the set of all regions: $\mathrm{S} \subset \mathrm{REGS}$. Given the coalition $\mathrm{S}$, we use the model to compute the change in utility (relative to the initial BEDS) for any member $\mathrm{s}$ of the coalition: $U^{\Phi}(S), s \in S$. A member s of this coalition will prefer membership in $\mathrm{S}$ to any other coalition A as long as $U^{s}(S)>U^{s}(A)$. Following Riezman (1999), we have:

Definition: A coalition $S$ blocks coalition A if for all regions $s \in S$ :

$$
U^{s}(S) \geq U^{s}(A) \quad \forall s \in S
$$

with $U^{\S}(S)>U^{\S}(A)$ for at least one $s$.

Then the core is defined as follows:

Definition: A coalition is in the core if it is not blocked by any feasible coalition.

Our approach, therefore, is to identify the coalitions which comprise the core for each mechanism. ${ }^{16}$ Of course, a core may be empty, or a core may have more than one coalition. A computer algorithm is used to identify the cores. This is not as straightforward as it was for Kennan and Riezman (1990) and Riezman (1999), which consider only 3 regions, ruling out the possibility of pairs of bilateral PTAs and bilateral-trilateral PTAs. For example, it is necessary to check whether any FTA-CU coalitions are blocked by an FTA-FTA or a CU-CU coalition. Moreover, there are restrictions on the blocking power of some coalitions. For example, coalitions with a single bloc cannot block coalitions with a pair of blocs, one of which is

\footnotetext{
${ }^{16}$ It is worth noting that this method of determining unblocked coalitions effectively presumes that PTAs form according to a process of unanimous regionalism, as opposed to open regionalism, as de-scribed in Yi (1996) and Andriamananjara (2002). That is, a coalition will expand to include another member only if no member of the larger coalition is worse off.
} 
Table 5. Benchmark and Nash Equilibrium Tariffs

\begin{tabular}{|c|c|c|c|c|c|c|c|c|c|c|c|c|c|c|c|c|c|c|c|c|}
\hline \multicolumn{21}{|c|}{ Benchmark Tariffs: } \\
\hline \multirow{2}{*}{$\begin{array}{l}\text { tariff on } \\
\text { imports } \\
\text { from }\end{array}$} & \multicolumn{4}{|c|}{ NA } & \multicolumn{4}{|c|}{ SA } & \multicolumn{4}{|c|}{$\mathrm{EU}$} & \multicolumn{4}{|c|}{ ASIA } & \multicolumn{4}{|c|}{ ROW } \\
\hline & SA & $\mathrm{EU}$ & ASIA & ROW & NA & $\mathrm{EU}$ & ASIA & ROW & NA & SA & ASIA & ROW & NA & SA & $\mathrm{EU}$ & ROW & NA & $\mathrm{SA}$ & $\mathrm{EU}$ & ASIA \\
\hline AGR & 7 & 4 & 3 & 12 & -3 & -1 & 7 & 6 & 11 & 7 & 5 & 14 & 101 & 20 & 22 & 29 & 12 & 15 & 26 & 14 \\
\hline FFM & 0 & 1 & 0 & 1 & 5 & 8 & 4 & 16 & 0 & 1 & 0 & 0 & 1 & 3 & 2 & 2 & 3 & 5 & 7 & 11 \\
\hline FOO & 11 & 15 & 7 & 10 & 11 & 10 & 3 & 6 & 21 & 31 & 29 & 23 & 25 & 21 & 36 & 21 & 34 & 16 & 28 & 37 \\
\hline TEX & 11 & 10 & 12 & 12 & 21 & 16 & 18 & 12 & 7 & 6 & 8 & 7 & 13 & 11 & 13 & 16 & 17 & 14 & 15 & 23 \\
\hline PPP & 1 & 2 & 2 & 1 & 8 & 9 & 12 & 9 & 2 & 4 & 3 & 2 & 4 & 3 & 9 & 11 & 10 & 13 & 8 & 16 \\
\hline CRP & 2 & 4 & 6 & 3 & 9 & 9 & 10 & 10 & 4 & 4 & 5 & 2 & 8 & 7 & 10 & 16 & 8 & 6 & 8 & 14 \\
\hline MET & 2 & 5 & 5 & 2 & 11 & 12 & 12 & 9 & 3 & 2 & 4 & 2 & 7 & 5 & 14 & 8 & 10 & 11 & 8 & 18 \\
\hline TRN & 1 & 3 & 3 & 2 & 16 & 18 & 16 & 16 & 3 & 4 & 7 & 5 & 7 & 10 & 19 & 19 & 11 & 15 & 11 & 19 \\
\hline MAN & 1 & 3 & 3 & 2 & 12 & 12 & 14 & 11 & 4 & 4 & 4 & 1 & 7 & 12 & 11 & 11 & 9 & 8 & 8 & 13 \\
\hline \multicolumn{21}{|c|}{ Nash Equilibrium Tariffs - Low Elasticity: } \\
\hline AGR & 145 & 141 & 149 & 143 & 56 & 62 & 62 & 60 & 84 & 95 & 82 & 98 & 118 & 87 & 74 & 89 & 84 & 84 & 89 & 84 \\
\hline FFM & 152 & 140 & 151 & 148 & 58 & 64 & 65 & 64 & 86 & 90 & 84 & 103 & 89 & 85 & 79 & 99 & 92 & 83 & 94 & 90 \\
\hline FOO & 136 & 136 & 147 & 139 & 55 & 59 & 58 & 58 & 79 & 87 & 77 & 85 & 92 & 81 & 73 & 82 & 80 & 79 & 84 & 78 \\
\hline TEX & 180 & 154 & 176 & 161 & 60 & 62 & 62 & 61 & 80 & 78 & 80 & 94 & 84 & 71 & 73 & 75 & 80 & 76 & 88 & 82 \\
\hline PPP & 139 & 141 & 157 & 142 & 61 & 66 & 65 & 65 & 86 & 89 & 82 & 99 & 95 & 87 & 76 & 85 & 84 & 84 & 94 & 85 \\
\hline CRP & 139 & 139 & 155 & 143 & 63 & 66 & 66 & 66 & 83 & 75 & 79 & 86 & 92 & 76 & 75 & 88 & 81 & 77 & 89 & 80 \\
\hline MET & 142 & 139 & 157 & 146 & 58 & 64 & 63 & 63 & 81 & 80 & 78 & 86 & 88 & 85 & 75 & 86 & 81 & 79 & 89 & 81 \\
\hline TRN & 132 & 141 & 159 & 143 & 56 & 62 & 64 & 62 & 77 & 68 & 73 & 70 & 81 & 66 & 69 & 72 & 78 & 77 & 86 & 83 \\
\hline MAN & 138 & 140 & 163 & 144 & 58 & 62 & 63 & 62 & 84 & 76 & 81 & 85 & 89 & 74 & 75 & 81 & 83 & 80 & 93 & 84 \\
\hline \multicolumn{21}{|c|}{ Nash Equilibrium Tariffs - High Elasticity: } \\
\hline AGR & 19 & 17 & 14 & 17 & 9 & 9 & 9 & 8 & 15 & 21 & 15 & 22 & 44 & 17 & 14 & 17 & 12 & 14 & 14 & 13 \\
\hline FFM & 19 & 17 & 16 & 19 & 9 & 9 & 10 & 10 & 16 & 18 & 15 & 20 & 18 & 18 & 16 & 20 & 11 & 10 & 10 & 11 \\
\hline FOO & 16 & 16 & 15 & 15 & 9 & 9 & 9 & 9 & 14 & 20 & 14 & 16 & 15 & 13 & 13 & 14 & 16 & 13 & 14 & 14 \\
\hline TEX & 24 & 18 & 20 & 18 & 12 & 10 & 10 & 9 & 13 & 13 & 13 & 16 & 12 & 11 & 12 & 11 & 13 & 12 & 15 & 14 \\
\hline PPP & 17 & 16 & 17 & 16 & 11 & 11 & 11 & 10 & 14 & 17 & 14 & 18 & 16 & 16 & 14 & 14 & 13 & 14 & 15 & 14 \\
\hline CRP & 17 & 17 & 18 & 17 & 13 & 12 & 12 & 12 & 14 & 13 & 13 & 15 & 16 & 13 & 13 & 16 & 12 & 11 & 14 & 12 \\
\hline MET & 17 & 17 & 18 & 17 & 11 & 11 & 11 & 11 & 13 & 13 & 12 & 15 & 14 & 15 & 14 & 15 & 13 & 13 & 13 & 13 \\
\hline TRN & 14 & 16 & 17 & 17 & 11 & 11 & 12 & 11 & 12 & 10 & 11 & 11 & 11 & 11 & $\begin{array}{l}14 \\
12\end{array}$ & 11 & $\begin{array}{l}10 \\
13\end{array}$ & $\begin{array}{l}10 \\
13\end{array}$ & $\begin{array}{l}10 \\
14\end{array}$ & 14 \\
\hline MAN & 16 & 16 & 19 & 16 & 11 & 11 & 12 & 11 & 14 & 13 & 13 & 14 & 14 & 12 & 13 & 13 & 13 & 13 & 15 & 13 \\
\hline
\end{tabular}


common to the single bloc [e.g., FTA(NA,SA) cannot block FTA(NA, SA)-FTA (EU,ASIA)]. On the other hand, the reverse blocking is admissible.

\section{Results}

Now that we have described how coalitions choose tariffs, and how regions evaluate membership in different coalitions, we can turn to the question of which coalitions will actually form. Before proceeding, we consider the outcome of this game if no PTAs were allowed at all. Relative to the initial BEDS, the only two alternatives would be the Nash equilibrium, where all regions charge individually optimal tariffs, or Global Free Trade (GFT), where all regions reduce all tariffs to zero. Welfare changes for each region under these two equilibria relative to the BEDS are reported in Table 6 below. ${ }^{17}$ As we would expect, each region is best off under Global Free Trade.

We begin by supposing that CUs set their CET according to Mechanism 1 and proceed to the other mechanisms. For the sake of brevity, we describe only the core coalitions, i.e., the set of coalitions which block all others. ${ }^{18}$ In each case, we also consider whether banning one type of PTA makes it more likely to observe GFT emerging endogenously as an equilibrium. Table 7 lists the coalition members in the core for each mechanism and across the various restrictions on the PTAs that are permitted.

Table 6. Eciency Gains without PTAs

\begin{tabular}{cccc}
\hline Region & BEDS & Nash & GFT \\
\hline NA & 0.000 & 0.019 & 0.258 \\
SA & 0.000 & -0.468 & 0.493 \\
EU & 0.000 & -0.234 & 0.010 \\
ASIA & 0.000 & -0.350 & 0.360 \\
ROW & 0.000 & -2.290 & 0.123 \\
\hline
\end{tabular}

Note: Eciency gains are the percentage change in income from the initial BEDS, measured by Hicksian equivalent variations.

\footnotetext{
${ }^{17}$ To give an idea of the relative size of the Nash equilibrium tariffs, Table 5 lists the Nash equilibrium tariffs on those goods for which regions charge optimal tariffs under the high and low elasticity cases, as well as the corresponding tariffs in the initial benchmark equilibrium.

${ }^{18}$ Detailed results, including all welfare changes, terms-of-trade changes, and all optimal tariff vectors, for all possible coalitions are available from the authors on request.
} 
Table 7. Core Coalitions by Mechanism and PTA Permitted Central Case (Medium) Elasticities

\begin{tabular}{|c|c|c|c|}
\hline Mech. & All PTAs & CUs only & FTAs only \\
\hline 1 & FTA(SA,ROW)-CU(NA,EU,ASIA) & Core is empty & $\begin{array}{l}\text { FTA(NA,EU,ASIA) } \\
\text { FTA(NA,EU,ASIA)-FTA(SA,ROW) } \\
\text { FTA(NA,SA,EU,ASIA) } \\
\text { FTA(NA,EU,ASIA,ROW) } \\
\text { GFT }\end{array}$ \\
\hline 2 & $\begin{array}{l}\text { CU(NA,EU,ASIA) } \\
\text { CU(NA,EU,ASIA)-CU(SA,ROW) } \\
\text { FTA(SA,ROW)-CU(NA,EU,ASIA) }\end{array}$ & $\begin{array}{l}\text { CU(NA,EU,ASIA) } \\
\text { CU(NA,EU,ASIA)-CU(SA,ROW) }\end{array}$ & same as Mechanism 1 \\
\hline 3 & $\begin{array}{l}\text { FTA(NA,EU,ASIA) } \\
\text { FTA(NA,EU,ASIA)-FTA(SA,ROW) } \\
\text { FTA(NA,SA,EU,ASIA) } \\
\text { FTA(NA,EU,ASIA,ROW) } \\
\text { GFT }\end{array}$ & $\begin{array}{l}\text { CU(NA,ASIA) } \\
\text { CU(NA,SA,ASIA) } \\
\text { CU(NA,ASIA,ROW) } \\
\text { CU(EU,ASIA,ROW) } \\
\text { CU(SA,EU)-CU(ASIA,ROW) } \\
\text { CU(NA,ASIA)-CU(EU,ROW) } \\
\text { CU(NA,SA)-CU(ASIA,ROW) } \\
\text { CU(NA,ASIA)-CU(SA,ROW) } \\
\text { CU(NA,SA)-CU(EU,ROW) } \\
\text { CU(NA,ASIA)-CU(SA,EU) } \\
\text { CU(NA,SA,EU)-CU(ASIA,ROW) } \\
\text { CU(NA,SA,ASIA)-CU(EU,ROW) } \\
\text { CU(NA,EU,ROW)-CU(SA,ASIA) } \\
\text { CU(NA,ASIA,ROW)-CU(SA,EU) } \\
\text { CU(SA,EU,ROW)-CU(NA,ASIA) } \\
\text { CU(EU,ASIA,ROW)-CU(NA,SA) } \\
\text { CU(NA,SA,EU,ASIA) } \\
\text { CU(NA,SA,ASIA,ROW) } \\
\text { CU(NA,EU,ASIA,ROW) } \\
\text { CU(SA,EU,ASIA,ROW) } \\
\text { GFT }\end{array}$ & same as Mechanism 1 \\
\hline 4 & $\begin{array}{l}\text { FTA(NA,ASIA,ROW)-FTA(SA,EU) } \\
\text { FTA(NA,SA,ASIA,ROW) } \\
\text { CU(EU,ASIA,ROW) } \\
\text { CU(SA,ROW)-CU(EU,ASIA) } \\
\text { CU(NA,SA)-CU(ASIA,ROW) } \\
\text { CU(NA,SA)-CU(EU,ROW) } \\
\text { CU(NA,ASIA)-CU(SA,EU) } \\
\text { CU(NA,SA,EU)-CU(ASIA,ROW) } \\
\text { CU(NA,SA,ASIA)-CU(EU,ROW) } \\
\text { CU(NA,EU,ASIA)-CU(SA,ROW) } \\
\text { CU(NA,ASIA,ROW)-CU(SA,EU) } \\
\text { CU(EU,ASIA,ROW)-CU(NA,SA) } \\
\text { CU(NA,SA,ASIA,ROW) } \\
\text { CU(NA,EU,ASIA,ROW) } \\
\text { CU(SA,EU,ASIA,ROW) } \\
\text { FTA(NA,SA,ROW)-CU(EU,ASIA) } \\
\text { FTA(NA,ASIA,ROW)-CU(SA,EU) } \\
\text { FTA(SA,ASIA,ROW)-CU(NA,EU) } \\
\text { FTA(EU,ASIA,ROW)-CU(NA,SA) } \\
\text { FTA(ASIA,ROW)-CU(NA,SA,EU) } \\
\text { FTA(EU,ROW)-CU(NA,SA,ASIA) } \\
\text { FTA(SA,ROW)-CU(NA,EU,ASIA) } \\
\text { FTA(SA,EU)-CU(NA,ASIA,ROW) } \\
\text { FTA(NA,ROW)-CU(SA,EU,ASIA) } \\
\text { FTA(SA,ROW)-CU(EU,ASIA) } \\
\text { FTA(NA,ROW)-CU(EU,ASIA) } \\
\text { FTA(ASIA,ROW)-CU(NA,EU) } \\
\text { FTA(ASIA,ROW)-CU(NA,SA) } \\
\text { FTA(EU,ROW)-CU(NA,SA) } \\
\text { FTA(SA,ASIA)-CU(NA,EU) } \\
\text { GFT }\end{array}$ & $\begin{array}{l}\text { CU(EU,ASIA,ROW) } \\
\text { CU(SA,ROW)-CU(EU,ASIA) } \\
\text { CU(NA,SA)-CU(ASIA,ROW) } \\
\text { CU(NA,SA)-CU(EU,ROW) } \\
\text { CU(NA,ASIA)-CU(SA,EU) } \\
\text { CU(NA,SA,EU)-CU(ASIA,ROW) } \\
\text { CU(NA,SA,ASIA)-CU(EU,ROW) } \\
\text { CU(NA,EU,ASIA)-CU(SA,ROW) } \\
\text { CU(NA,ASIA,ROW)-CU(SA,EU) } \\
\text { CU(EU,ASIA,ROW)-CU(NA,SA) } \\
\text { CU(NA,SA,ASIA,ROW) } \\
\text { CU(NA,EU,ASIA,ROW) } \\
\text { CU(SA,EU,ASIA,ROW) } \\
\text { GFT }\end{array}$ & $\begin{array}{l}\text { FTA(NA,SA)-FTA(ASIA,ROW) } \\
\text { FTA(NA,SA)-FTA(EU,ROW) } \\
\text { FTA(NA,SA,EU)-FTA(ASIA,ROW) } \\
\text { FTA(NA,SA,ASIA)-FTA(EU,ROW) } \\
\text { FTA(NA,EU,ROW)-FTA(SA,ASIA) } \\
\text { FTA(NA,ASIA,ROW)-FTA(SA,EU) } \\
\text { FTA(FU,ASIA, ROW)-FTA(NA,SA) } \\
\text { FTA(NA,SA,ASIA,ROW) } \\
\text { FTA(NA,EU,ASIA,ROW) } \\
\text { GFT }\end{array}$ \\
\hline $4 a$ & Core is empty & Core is empty & Core is empty \\
\hline
\end{tabular}




\section{A. Mechanism 1}

The elements of the core when CUs choose their CET according to Mechanism 1 and both CUs and FTAs are permitted are listed in the upper left-hand cell of Table 7.

We note immediately that GFT is not an element of the core. GFT is blocked by the trilateral coalition CU(NA,EU,ASIA) (and a number of other PTAs) since each member of this coalition is better off than under GFT. In this example, allowing PTAs to exist will not allow GFT to emerge endogenously.

Now we consider whether restricting the types of PTAs that are allowed to form would result in Global Free Trade becoming an element of the core. If FTAs are banned, so that only CUs are permitted, it turns out that the core is empty. Not only is GFT not in the core, but nor is any other coalition. But if we ban CUs and allow only FTAs, then there are four FTAs in the core - listed in the upper right-hand cell of Table 7: FTA(NA,EU,ASIA), FTA(NA,EU,ASIA)-FTA(SA,ROW), FTA(NA, SA,EU,ASIA), and FTA(NA,EU,ASIA,ROW) - and GFT is also in the core. Given the equilibrium concept we are using, we cannot choose between the five PTAs in the core. However, we can conclude that by restricting PTAs to allow FTAs and not CUs, it is possible that GFT emerges endogenously as an equilibrium. Intuitively, banning CUs restricts the use of market power: members can no longer internalize the tariff externality by choosing a CET.

\section{B. Mechanism 2}

Under Mechanism 2, CUs choose their CET so that no CU member is made worse off. The three coalitions which are in the core when all PTAs are permitted (see Table 7) do not include GFT, so we must conclude again that allowing PTAs to exist will not allow GFT to emerge endogenously. In this example, the three large regions (NA, EU, and ASIA) form a customs union that can be matched by the smaller regions forming either a CU or an FTA. Under Mechanism 2, SA is better-off forming a CU or FTA with ROW to counter CU(NA,EU,ASIA) but ROW is actually worse-off under these circumstances than going it alone against CU(NA,EU,ASIA). This, of course, means that CU(NA,EU,ASIA) is not blocked by either CU(NA,EU,ASIA)-CU(SA,ROW) or CU(NA,EU,ASIA)-FTA(SA, ROW), which is why all three are in the core.

We argued in Section 3 that without side payments, choosing the CET according to Mechanism 2 leaves unexploited gains to a $\mathrm{CU}$ setting its CET. While 
incorporating side payments is left to further research, we note that incorporating side payments into Mechanism 2 is unlikely to affect the result that GFT is not in the core, since incorporating side payments should only allow members of a $\mathrm{CU}$ to increase gains from coalition membership, making it even less likely that GFT would be preferred for any CU member.

As was the case under Mechanism 1, GFT will not emerge endogenously if FTAs are banned and only CUs are allowed. If CUs are banned and only FTAs are allowed, the core will look the same as in 4.1, since the core when CUs are banned is clearly not affected by the way CUs choose their CET. So again we find that banning CUs and allowing FTAs implies that GFT is in the core, although it is not certain that GFT will be the ultimate outcome.

\section{Mechanism 3}

Mechanism 3 imposes a considerable amount of discipline on any CU, since regions which join to form a CU cannot exercise any market power against nonmembers to their own benefit. Accordingly, CETs are considerably lower under Mechanism 3 than under either Mechanism 1 or 2. For example, the average CET in CU(NA,EU,ASIA) is $42.4 \%(30.1 \%)$ and $46.3 \%$ (36.4\%) on imports from SA and ROW, respectively, under Mechanism 1 (Mechanism 2). ${ }^{19}$ Under Mechanism 3 , the average CET in CU(NA,EU,ASIA) is $3.4 \%$ and $4.1 \%$ on imports from SA and ROW, respectively. Thus, CUs can wield much less market power on world output markets under Mechanism 3 because their CET is constrained. Coalitions, therefore, typically do better by forming FTAs rather than CUs. In particular, when both FTAs and CUs are permitted, all CUs are blocked under Mechanism 3, and the core consists of: FTA(NA,EU,ASIA), FTA(NA,EU,ASIA)-FTA(SA,ROW), FTA(NA,SA,EU,ASIA), FTA(NA,EU,ASIA,ROW), and GFT. Even if all PTAs are allowed, GFT is in the core, so it is possible that GFT emerges endogenously as an equilibrium. It is worth nothing that this is the same configuration of the core as under Mechanisms 1 and 2 when CUs are banned and only FTAs are allowed.

Now suppose we consider restricting the type of PTAs which are permitted. Since FTAs dominate CUs under Mechanism 3, the core is unaltered if we ban CUs. Under Mechanism 3, there are no CUs in the core even if the type of PTA is unrestricted.

\footnotetext{
${ }^{19}$ Under Mechanism 1 (Mechanism 2), tariffs range from a low of 23\% (14\%) and 29\% (22\%) on imports of Transport Equipment from SA and ROW, respectively, to a high of $57 \%$ (47\%) on imports of AGR from SA and $69 \%$ (55\%) on imports of FFM from ROW.
} 
If we ban FTAs and allow only CUs where the CET is set according to Mechanism 3, then we have effectively implemented the rule implied by Bhagwati (1992). In this case, the core expands to comprise 20 different CUs and GFT. Unlike Mechanisms 1 and 2, banning FTAs and constraining CUs to set their Common External Tariff according to the rule specified by Bhagwati (1992), Global Free Trade emerges as an element of the core.

\section{Mechanism 4}

Under Mechanism 4, if regions join to form an FTA, each member-regionÅfs tariffs on non-member trade remain at pre-FTA levels, while if regions form a CU, tariffs are set at the coalition average of pre-CU tariffs. That is, some CU members will raise tariffs to the coalition average while others will lower tariffs. For CUs, Mechanism 4 allows tariffs to be slightly higher than under Mechanism 3. But Mechanism 4 places much more discipline of FTAs than Mechanism 3. Since regions are free to charge optimal tariffs if they do not join a PTA, Mechanism 4 makes it much less desirable for regions to join a PTA, since their tariffs on nonmember trade are then effectively bound at pre-PTA levels. For this reason, we can expect more coalitions to remain unblocked under Mechanism 4, since many regions would be worse off joining a coalition than remaining outside the coalition and charging optimal tariffs. For example, under the coalition FTA(NA,ASIA), NA receives a welfare gain of $0.12 \%$, ASIA of $0.04 \%$, and EU of $-0.01 \%$. Were EU to join in an FTA with NA and ASIA, NA and ASIA would both see a welfare increase (to $0.22 \%$ and $0.26 \%$ for NA and ASIA, respectively), but welfare in EU would fall by $0.18 \% .{ }^{20}$ As expected, the effect of the tariff constraints on PTAs is to drastically increase the number of coalitions in the core, which includes GFT. The core only includes 2 strictly FTA coalitions (not including GFT), compared with 12 strictly CU coalitions and 15 FTA-CU coalitions.

When FTAs are banned, the core shrinks by the number of coalitions with at least one FTA and adds CU(SA,ROW)-CU(EU,ASIA), which was blocked by an FTA coalition when all PTAs were permitted. When CUs are banned, the number of FTAs in the core increases markedly, since many FTAs are blocked only by CUs. Note that GFT is an element of the core regardless what kind of PTA is permitted.

\footnotetext{
${ }^{20}$ Of course, FTA(NA,ASIA) and FTA(NA,EU,ASIA) are only two of 150 possible coalitions which could form. Nevertheless, FTA(NA,ASIA) is the only purely bilateral FTA where both members of the FTA are better off relative to the BEDS under Mechanism 4.
} 


\section{E. Mechanism 4a}

It may seem overly restrictive to constrain PTA members to not raise their tariffs on non-member trade while allowing regions that have not joined a PTA to raise tariffs to their optimal level. As noted in Section 3, GATT Art.XXIV disciplines PTAs, but the tariff bindings under Art.II also impose some discipline on all WTO members. Under Mechanism 4a, we presume that the tariffs of all regions are effectively bound at the level implied by the BEDS. Under this mechanism, there are only two reasons why regions change tariffs: (i) PTA members reduce tariffs on intra-PTA trade to zero, and (ii) CU members adjust tariffs on non-member trade to CU-average levels. Under Mechanism 4a, the core is empty regardless what kind of PTA is permitted.

\section{F. Sensitivity Analysis}

As noted at the end of Section 2, the trade elasticities reported in Table 3 are very important in affecting a regionÅfs optimal tariffs. We conduct sensitivity analysis on this variable, repeating all simulations for low $\left(v_{i}^{l o}=0.5 \times v_{i}\right)$ and high $\left(v_{i}^{h i}=2 \times v_{i}\right)$ values for the independently specified parameters _ $\mathrm{i}$ and $\mathrm{i}_{\mathrm{i}}$ which affect the trade elasticities. ${ }^{21}$ The coalition members in the core for each mechanism for high and low trade elasticities are listed in Tables 8 and 9, respectively.

When both CUs and FTAs set optimal tariffs against non-members (as in Mechanisms 1 and 2) and both types of PTAs are permitted, GFT is in the core only when trade elasticities are set at their lowest level (i.e., when regions have the most market power in world output markets). It is worth noting that the core is very similar for different values of the trade elasticity under Mechanisms 1 and 2. In fact, the core is identical under Mechanism 2 when all PTAs are permitted or when only CUs are permitted for the central case (Table 6) and high values (Table 7) of the trade elasticity, and all of these coalitions (except CU(NA,EU,ASIA)-CU $(\mathrm{SA}, \mathrm{ROW}))$ are also in the core when the trade elasticity is set at $v_{i}^{l o}$. Thus, when PTAs set optimal tariffs, the core seems very robust to different specifications of the trade elasticity.

Under Mechanism 3, FTAs set optimal tariffs against non-members while CUs are constrained against raising their CET, so FTAs dominate CUs in the core when

\footnotetext{
${ }^{21}$ Recall that the trade elasticity can be approximated by the substitution elasticity between imports from different regions, $\tau_{i}$, which is set according to $\tau_{i}=2 \times v_{i}$.
} 
both types of PTAs are permitted. This result obtains regardless of the way that trade elasticities are specified. Under Mechanism 4, GFT is in the core regardless of the specification of the substitution elasticities $v_{i}$ and $\tau_{i}$. The lower the values of these parameters, the lower the trade elasticity, the more market power regions have in world output markets, and the larger the number of coalitions in the core. Lastly, the core is empty under Mechanism 4a except when $v_{i}=v_{i}^{h i}$, in which case GFT is in the core if only FTAs are permitted.

\section{G. Discussion}

Tables 9 and 10 summarize, respectively, two important aspects of the results from all the simulations: whether the core includes GFT and the size of the core.

Table 9 shows that the question of which mechanisms allow GFT into the core is relatively clear cut: If only FTAs are permitted, GFT is always in the core (except

Table 8. Core Coalitions by Mechanism and PTA Permitted -High Elasticities

\begin{tabular}{|c|c|c|c|}
\hline Mech. & All PTAs & CUs only & FTAs only \\
\hline 1 & $\begin{array}{l}\text { CU(NA,EU,ASIA)-CU(SA,ROW) } \\
\text { FTA(SA,ROW)-CU(NA,EU,ASIA) }\end{array}$ & CU(NA,EU,ASIA)-CU(SA,ROW) & $\begin{array}{l}\text { FTA(NA,EU)-FTA(ASIA,ROW) } \\
\text { FTA(NA,EU,ASIA)-FTA(SA,ROW) } \\
\text { FTA(SA,ASIA,ROW)-FTA(NA,EU) }\end{array}$ \\
\hline 2 & $\begin{array}{l}\text { CU(NA,EU,ASIA) } \\
\text { CU(NA,EU,ASIA)-CU(SA,ROW) } \\
\text { FTA(SA,ROW)-CU(NA,EU,ASIA) }\end{array}$ & $\begin{array}{l}\text { CU(NA,EU,ASIA) } \\
\text { CU(NA,EU,ASIA)-CU(SA,ROW) }\end{array}$ & same as Mechanism 1 \\
\hline 3 & $\begin{array}{l}\text { FTA(NA,EU)-FTA(ASIA,ROW) } \\
\text { FTA(NA,EU,ASIA)-FTA(SA,ROW) } \\
\text { FTA(SA,ASIA,ROW)-FTA(NA,EU) }\end{array}$ & $\begin{array}{l}\text { CU(NA,SA,ASIA) } \\
\text { CU(NA,ASIA,ROW) } \\
\text { CU(NA,ROW)-CU(SA,ASIA) } \\
\text { CU(NA,ROW)-CU(SA,EU) } \\
\text { CU(NA,SA,EU)-CU(ASIA,ROW) } \\
\text { CU(NA,EU,ASIA)-CU(SA,ROW) } \\
\text { CU(NA,EU,ROW)-CU(SA,ASIA) } \\
\text { CU(NA,ASIA,ROW)-CU(SA,EU) } \\
\text { CU(SA,EU,ASIA)-CU(NA,ROW) } \\
\text { CU(EU,ASIA,ROW)-CU(NA,SA) } \\
\text { CU(NA,SA,ASIA,ROW) } \\
\text { CU(NA,EU,ASIA,ROW) } \\
\text { GFT }\end{array}$ & same as Mechanism 1 \\
\hline 4 & $\begin{array}{l}\text { FTA(NA,EU,ASIA,ROW) } \\
\text { CU(NA,ROW)-CU(EU,ASIA) } \\
\text { CU(NA,ASIA,ROW)-CU(SA,EU) } \\
\text { CU(SA,EU,ASIA)-CU(NA,ROW) } \\
\text { CU(EU,ASIA,ROW)-CU(NA,SA) } \\
\text { CU(NA,SA,EU,ASIA) } \\
\text { CU(NA,EU,ASIA,ROW) } \\
\text { FTA(NA,ASIA,ROW)-CU(SA,EU) } \\
\text { FTA(EU,ASIA,ROW)-CU(NA,SA) } \\
\text { GFT }\end{array}$ & $\begin{array}{l}\text { CU(NA,ROW)-CU(EU,ASIA) } \\
\text { CU(NA,ASIA,ROW)-CU(SA,EU) } \\
\text { CU(SA,EU,ASIA)-CU(NA,ROW) } \\
\text { CU(EU,ASIA,ROW)-CU(NA,SA) } \\
\text { CU(NA,SA,EU,ASIA) } \\
\text { CU(NA,EU,ASIA,ROW) } \\
\text { GFT }\end{array}$ & $\begin{array}{l}\text { FTA(NA,EU,ASIA) } \\
\text { FTA(NA,ASIA,ROW)-FTA(SA,EU) } \\
\text { FTA(EU,ASIA,ROW)-FTA(NA,SA) } \\
\text { FTA(NA,SA,EU,ASIA) } \\
\text { FTA(NA,EU,ASIA,ROW) } \\
\text { GFT }\end{array}$ \\
\hline $4 a$ & CU(SA,EU,ASIA,ROW) & CU(SA,EU,ASIA,ROW) & $\begin{array}{l}\text { FTA(EU,ASIA,ROW) } \\
\text { FTA(NA,EU,ASIA,ROW) } \\
\text { GFT }\end{array}$ \\
\hline
\end{tabular}


Table 8. Core Coalitions by Mechanism and PTA Permitted -Low Elasticities (continued)

\begin{tabular}{|c|c|c|c|}
\hline Mech. & All PTAs & CUs only & FTAs only \\
\hline 4 & $\begin{array}{l}\text { FTA(NA,SA,EU)-CU(ASIA,ROW) } \\
\text { FTA(NA,SA,ASIA)-CU(EU,ROW) } \\
\text { FTA(NA,SA,ROW)-CU(EU,ASIA) } \\
\text { FTA(NA,EU,ROW)-CU(SA,ASAA) } \\
\text { FTA(NA,ASIA,ROW)-CU(SA,EU) } \\
\text { FTA(SA,EU,ASIA)-CUUNA,ROW) } \\
\text { FTA(SA,EU,ROW)-CU(NA,ASIA) } \\
\text { FTA(EU,ASIA,ROW)-CU(NA,SA) } \\
\text { FTA(EU,ROW)-CU(NA,SA,ASA) } \\
\text { FTA(SA,ROW)-CU(NA,EU,ASIA) } \\
\text { FTA(SA,ASIA)-CU(NA,EU,ROW) } \\
\text { FTA(SA,EU)-CUUA,ASU,ROW) } \\
\text { FTA(NA,ROW)-CU(SA,EU,ASIA) } \\
\text { FTA(NA,ASIA)-CU(SA,EU,ROW) } \\
\text { FTA(NA,EU)-CU(SA,ASUA,ROW) } \\
\text { FTA(NA,SA)-CU(EU,ASIA,ROW) } \\
\text { FTA(SA,EU)-CU(ASIA,ROW) } \\
\text { FTA(SA,ROW)-CU(EU,ASIA) } \\
\text { FTA(NA,EU)-CU(ASIA,ROW) } \\
\text { FTA(NA,ROW)-CU(EU,ASIA) } \\
\text { FTA(NA,SA)-CU(ASIA,ROW) } \\
\text { FTA(NA,ROW)-CU(SA,ASIA) } \\
\text { FTA(NA,,RA)-CUEU,ROW) } \\
\text { FTA(NA,ROW)-CU(SA,EU) } \\
\text { FTA(NA,SA)-CU(EU,ASIA) } \\
\text { FTA(NA,EU)-CU(SA,ASAA) } \\
\text { FTA(NA,ASIA)-CU(SA,EU) } \\
\text { FTA(EU,ROW)-CU(NA,ASIA) } \\
\text { FTA(SA,ASIA)-CU(NA,ROW) } \\
\text { FTA(EU,ROW)-CU(NA,SA) } \\
\text { FTA(SA,ROW)-CU(NA,EU) } \\
\text { FTA(SA,ASIA)-CU(NA,EU) } \\
\text { FTA(SA,EU)-CU(NA,ASIA) } \\
\text { GFT }\end{array}$ & & \\
\hline $4 \mathrm{a}$ & Core is empty & Core is empty & Core is empty \\
\hline
\end{tabular}

for Mechanism 1 in the high elasticity case); if only CUs are permitted, GFT is in the core only if tariffs are constrained in some way (except for the low elasticity case). If all kinds of PTA are permitted, the core seems to inherit the properties of the CU-only core: only if tariffs are constrainedeither at their pre-PTA levels or at the lowest level of pre-union membersdoes the core include GFT. Generally speaking, therefore, both the Bhagwati rule and GATT Art.XXIV are sufficient to guarantee that GFT is in the core. Such restrictions are not necessary for GFT to be in the core, however, for unrestricted FTAs also imply that GFT is in the core.

In terms of the 'building blocks vs. stumbling blocks' literature, it follows that CUs pose more of a stumbling block to Global Free Trade, while FTAs do not block GFT from the core. When CUs are allowed to choose tariffs optimally (i.e., Mechanisms 1 and 2)

GFT is not an element of the core when CUs are allowed. This reflects the observation made by Kennan and Riezman (1990) that CUs internalize the tariff externality between member countries and set higher tariffs than FTAs, implying 
Table 9. Core Coalitions by Mechanism and PTA Permitted -Low Elasticities

\begin{tabular}{|c|c|c|c|}
\hline Mech. & All PTAs & CUs only & FTAs only \\
\hline 1 & $\begin{array}{l}\text { FTA(SA,EU,ASIA,ROW) } \\
\text { CU(NA,SA,EU,ASIA) } \\
\text { CU(NA,SA,EU,ROW) } \\
\text { CU(NA,EU,ASIA,ROW) } \\
\text { FTA(ASIA,ROW)-CU(NA,SA,EU) } \\
\text { FTA(SA,ROW)-CU(NA,EU,ASIA) } \\
\text { FTA(SA,ASIA)-CU(NA,EU,ROW) } \\
\text { GFT }\end{array}$ & $\begin{array}{l}\text { CU(NA,SA,EU,ASIA) } \\
\text { CU(NA,SA,EU,ROW) } \\
\text { CU(NA,EU,ASIA,ROW) } \\
\text { GFT }\end{array}$ & $\begin{array}{l}\text { FTA(NA,EU, ASIA) } \\
\text { FTA(NA,EU,ASIA)-FTA(SA,ROW) } \\
\text { FTA(SA,ASIA,ROW)-FTA(NA,EU) } \\
\text { FTA(NA,SA, EU,ASIA) } \\
\text { FTA(NA,EU,ASIA,ROW) } \\
\text { FTA(SA,EU,ASIA,ROW) } \\
\text { GFT }\end{array}$ \\
\hline 2 & $\begin{array}{l}\text { FTA(NA,EU,ASIA,ROW) } \\
\text { FTA(SA,EU,ASIA,ROW) } \\
\text { CU(NA,EU,ASIA) } \\
\text { FTA(SA,ROW)-CU(NA,EU,ASIA) } \\
\text { GFT }\end{array}$ & $\begin{array}{l}\text { CU(NA,EU,ASIA) } \\
\text { CU(EU,ASIA,ROW) } \\
\text { CU(SA,ASIA)-CU(EU,ROW) } \\
\text { CU(NA,EU,ASIA)-CU(SA,ROW) } \\
\text { CU(SA,ASIA, ROW)-CU(NA,EU) } \\
\text { CU(NA,EU,ASIA,ROW) } \\
\text { GFT }\end{array}$ & same as Mechanism 1 \\
\hline 3 & $\begin{array}{l}\text { FTA(NA,EU,ASIA) } \\
\text { FTA(NA,EU,ASIA)-FTA(SA,ROW) } \\
\text { FTA(NA,SA,EU,ASIA) } \\
\text { FTA(NA,EU,ASIA,ROW) } \\
\text { FTA(SA,EU,ASIA,ROW) } \\
\text { GFT }\end{array}$ & $\begin{array}{l}\text { CU(NA,EU,ASIA) } \\
\text { CU(EU,ASIA,ROW) } \\
\text { CU(SA,EU)-CU(ASIA,ROW) } \\
\text { CU(SA,ASIA)-CU(EU,ROW) } \\
\text { CU(NA,ASIA)-CU(EU,ROW) } \\
\text { CU(NA,SA)-CU(ASIA,ROW) } \\
\text { CU(NA,SA)-CU(EU,ROW) } \\
\text { CU(NA,ASIA)-CU(SA,EU) } \\
\text { CU(NA,SA,EU)-CU(ASIA,ROW) } \\
\text { CU(NA,SA,ASIA)-CU(EU,ROW) } \\
\text { CU(NA,EU,ROW)-CU(SA,ASIA) } \\
\text { CU(NA,ASIA,ROW)-CU(SA,EU) } \\
\text { CU(SA,EU,ROW)-CU(NA,ASIA) } \\
\text { CU(NA,SA,EU,ASIA) } \\
\text { CU(NA,SA,ASIA,ROW) } \\
\text { CU(NA,EU,ASIA,ROW) } \\
\text { CU(SA,EU,ASIA,ROW) } \\
\text { GFT }\end{array}$ & same as Mechanism 1 \\
\hline 4 & $\begin{array}{l}\text { FTA(NA,EU,ASIA) } \\
\text { FTA(EU,ASIA,ROW) } \\
\text { FTA(NA,SA)-FTA(EU,ROW) } \\
\text { FTA(NA,ASIA)-FTA(SA,EU) } \\
\text { FTA(NA,SA,ASIA)-FTA(EU,ROW) } \\
\text { FTA(NA,EU,ROW)-FTA(SA,ASIA) } \\
\text { FTA(NA,ASIA,ROW)-FTA(SA,EU) } \\
\text { FTA(EU,ASIA,ROW)-FTA(NA,SA) } \\
\text { FTA(NA,SA,EU,ASIA) } \\
\text { FTA(NA,SA,ASIA,ROW) } \\
\text { FTA(NA,EU,ASIA,ROW) } \\
\text { FTA(SA,EU,ASIA,ROW) } \\
\text { CU(NA,EU,ASIA) } \\
\text { CU(EU,ASIA,ROW) } \\
\text { CU(SA,EU)-CU(ASIA,ROW) } \\
\text { CU(NA,ASIA)-CU(EU,ROW) } \\
\text { CU(NA,SA)-CU(ASIA,ROW) } \\
\text { CU(NA,SA)-CU(EU,ROW) } \\
\text { CU(NA,ASIA)-CU(SA,EU) } \\
\text { CU(NA,SA,EU)-CU(ASIA,ROW) } \\
\text { CU(NA,SA,ASIA)-CU(EU,ROW) } \\
\text { CU(NA,EU,ROW)-CU(SA,ASIA) } \\
\text { CU(NA,ASIA,ROW)-CU(SA,EU) } \\
\text { CU(SA,EU,ROW)-CU(NA,ASIA) } \\
\text { CU(EU,ASIA,ROW)-CU(NA,SA) } \\
\text { CU(NA,SA,EU,ASIA) } \\
\text { CU(NA,SA,ASIA,ROW) } \\
\text { CU(NA,EU,ASIA,ROW) } \\
\text { CU(SA,EU,ASIA,ROW) }\end{array}$ & $\begin{array}{l}\text { CU(NA,EU,ASIA) } \\
\text { CU(EU,ASIA,ROW) } \\
\text { CU(SA,EU)-CU(ASIA,ROW) } \\
\text { CU(NA,ASIA)-CU(EU,ROW) } \\
\text { CU(NA,SA)-CU(ASIA,ROW) } \\
\text { CU(NA,SA)-CU(EU,ROW) } \\
\text { CU(NA,ASIA)-CU(SA,EU) } \\
\text { CU(NA,SA,EU)-CU(ASIA,ROW) } \\
\text { CU(NA,SA,ASIA)-CU(EU,ROW) } \\
\text { CU(NA,EU,ROW)-CU(SA,ASIA) } \\
\text { CU(NA,ASIA,ROW)-CU(SA,EU) } \\
\text { CU(SA,EU,ROW)-CU(NA,ASIA) } \\
\text { CU(EU,ASIA,ROW)-CU(NA,SA) } \\
\text { CU(NA,SA,EU,ASIA) } \\
\text { CU(NA,SA,ASIA,ROW) } \\
\text { CU(NA,EU,ASIA,ROW) } \\
\text { CU(SA,EU,ASIA,ROW) } \\
\text { GFT }\end{array}$ & $\begin{array}{l}\text { FTA(NA,EU,ASIA) } \\
\text { FTA(EU,ASIA,ROW) } \\
\text { FTA(SA,EU)-FTA(ASIA,ROW) } \\
\text { FTA(NA,SA)-FTA(ASIA,ROW) } \\
\text { FTA(NA,SA)-FTA(EU,ROW) } \\
\text { FTA(NA,ASIA)-FTA(SA,EU) } \\
\text { FTA(NA,SA,EU)-FTA(ASIA,ROW) } \\
\text { FTA(NA,SA,ASIA)-FTA(EU,ROW) } \\
\text { FTA(NA,EU,ROW)-FTA(SA,ASIA) } \\
\text { FTA(NA,ASIA,ROW)-FTA(SA,EU) } \\
\text { FTA(EU,ASIA,ROW)-FTA(NA,SA) } \\
\text { FTA(NA,SA,EU,ASIA) } \\
\text { FTA(NA,SA,ASIA,ROW) } \\
\text { FTA(NA,EU,ASIA,ROW) } \\
\text { FTA(SA,EU,ASIA,ROW) } \\
\text { GFT }\end{array}$ \\
\hline
\end{tabular}


Table 10. Is Global Free Trade in the Core?

\begin{tabular}{cccccccccc}
\hline & \multicolumn{3}{c}{ All PTAs } & \multicolumn{3}{c}{ CUs only } & \multicolumn{3}{c}{ FTAs only } \\
\cline { 2 - 10 } & \multicolumn{3}{c}{ Trade elasticities } & \multicolumn{3}{c}{ Trade elasticities } & \multicolumn{3}{c}{ Trade elasticities } \\
\hline Mechanism & Low & Medium & High & Low & Medium & High & Low & Medium & High \\
1 & Yes & No & No & Yes & No & No & Yes & Yes & No \\
2 & Yes & No & No & Yes & $\mathrm{N}^{\dagger}$ & No & & & \\
3 & Yes & Yes & No & Yes & Yes & Yes & & & \\
4 & Yes & Yes & Yes & Yes & Yes & Yes & Yes & Yes & Yes \\
$4 a$ & No $^{\dagger}$ & No $^{\dagger}$ & No & No $^{\dagger}$ & No $^{\dagger}$ & No & No $^{\dagger}$ & No $^{\dagger}$ & Yes $^{\dagger}$ \\
\hline
\end{tabular}

*Same as Mechanism 1.

${ }^{\dagger}$ The core is empty.

larger welfare gains to CUs than FTAs. Optimal tariffs set by a CU are often three times larger than the optimal tariffs set by the same FTA. However, when the tariffs set by CUs are constrained in some way, GFT emerges in the core when CUs are allowed. In this sense, our results confirm both Bhagwati (1992), in that restrictions on tariffs set by a CU can support GFT, and Yi (1996), in that CUs are stumbling blocks to GFT under 'unanimous regionalism'.22

Another observation from Table 9 is that, regardless of mechanism, GFT is less likely to be an element of the core the higher are the trade elasticities. Higher trade elasticities reduce the market power of coalitions and of individual regions and, hence, result in lower optimal tariffs. In fact, for the high trade elasticities, almost all optimal tariffs in the Nash equilibrium (with no PTAs) are between 8-20\%, and three regions (NA, SA, and ASIA) are actually better-off in the Nash equilibrium relative to the benchmark. For the high value of the trade elasticities, many PTAs have tariffs that are very close to GFT levels (i.e., zero tariffs), implying that the relative benefits of GFT are not as great as they are with lower trade elasticities and, as such, GFT is less likely to appear in the core.

Table 10 shows that the size of the core increases with the degree of the restrictions on tariffs. Under Mechanisms 1 and 2 the cores are quite small: less than 10 percent of the total coalitions when only FTAs are permitted, and less than 4 percent when only CUs are permitted. ${ }^{23}$ Under Mechanisms 3 and 4, on the other hand, the size of the core increases dramatically for CUs. In the case of Mechanism

\footnotetext{
${ }^{22}$ As defined by Yi (1996), 'unanimous regionalism' gives any region veto power over a coalition of which they are a member, which is the same as the concept of a blocking coalition used here.

${ }^{23}$ Recall there are 152 possible coalitions when all PTAs are permitted and 52 possible coalitions when only CUs or only FTAs are permitted.
} 
Table 11. Core Size

\begin{tabular}{cccccccccc}
\hline & \multicolumn{3}{c}{ All PTAs } & \multicolumn{3}{c}{ CUs only } & \multicolumn{3}{c}{ FTAs only } \\
\cline { 2 - 10 } Mechanism & \multicolumn{2}{c}{ Trade elasticities } & \multicolumn{2}{c}{ Trade elasticities } & \multicolumn{3}{c}{ Trade elasticities } \\
& Low & Medium & High & Low & Medium & High & Low & Medium & High \\
\hline 1 & 8 & 1 & 2 & 4 & 0 & 1 & 7 & 5 & 3 \\
2 & 5 & 3 & 3 & 7 & 2 & 2 & $*$ & $*$ & $*$ \\
3 & 6 & 5 & 3 & 18 & 21 & 13 & $*$ & $*$ & $*$ \\
4 & 63 & 31 & 10 & 18 & 14 & 7 & 16 & 10 & 6 \\
$4 \mathrm{a}$ & 0 & 0 & 1 & 0 & 0 & 1 & 0 & 0 & 3 \\
\hline
\end{tabular}

*Same as Mechanism 1.

4, the cores comprise around one-third the total number of coalitions irrespective of the kind of PTA permitted. When they are allowed to charge optimal tariffs, PTAs set higher tariffs and earn a higher welfare gain, so many more coalitions are blocked under Mechanisms 1 and 2. But when PTAs are constrained from raising tariffs, welfare gains to regions forming PTAs are much more modest, due only to trade creation arising from intra-PTA tariff reductions, so more coalitions remain unblocked under Mechanisms 3. Under Mechanism 4, even FTAs are constrained, and even more coalitions remain unblocked.

Table 10 also shows that the number of coalitions in the core decreases as trade elasticities increase for all but Mechanism 4a. When trade elasticities are set at their lowest level, implying that regions have the most market power in world output markets, there is a large number of unblocked coalitions. Similarly, when trade elasticities take on high values, the number of unblocked coalitions decreases, i.e., the number of coalitions in the core falls. There is thus an inverse relationship between core size and the size of the trade elasticities.

Table 10 shows that the core is empty for Mechanism 4a in all but the high elasticity case. In a sense, Mechanism 4a is the most 'realistic', as it incorporates the constraints on tariff setting by PTA members (GATT Art.XXIV) and on nonmembers in (Art.II) required by current trade rules. All regions are constrained to not raise tariffs, whether they act as individual regions or members of a PTA. As such, welfare gains to PTA members and welfare losses to non-members implied by trade diversion due to the formation of PTAs are greatly reduced. The primary source of welfare gains becomes trade creation due to the removal of intra-union tariffs. These gains will be greater the higher the trade elasticity, explaining why some coalitions remain unblocked under Mechanism 4a when trade elasticities are set at their highest level. With lower trade elasticities, welfare gains due to PTA 
formation are very small under Mechanism 4a, resulting in an empty core.

\section{Conclusion}

The paper examines the issue of whether Global Free Trade is feasible in a world that permits the formation of Preferential Trade Agreements like Customs Unions and Free Trade Areas. The novel aspects of the paper are twofold: The various trading arrangements are evaluated using actual trade data, and the formation of Preferential Trading Agreements between regions is allowed to occur endogenously on the basis of each region's self interest. The paper thus brings together two strands of trade literature: work on endogenous coalition formation with artificial data and work with actual trade data relying on exogenous coalition formation.

Results highlight the crucial role played by the Common External Tariff set by a Customs Union. Regions joining together can wield more market power on world output markets and increase member welfare more by forming a Customs Union, and jointly setting a CET on trade with non-members, than by forming a Free Trade Area, and individually setting their tariffs on non-member trade. However, if Customs Unions are constrained so that the CET is set at the level of the Customs Union member with the lowest initial tariff on non-member trade, as suggested by Bhagwati (1992) then their market power is reduced to the point where regions prefer to form Free Trade Areas.In terms of the 'building blocks vs. stumbling blocks' literature, our results suggest that Customs Unions present more of an obstacle to Global Free Trade than Free Trade Areas. When they are allowed to charge optimal tariffs, Customs Unions set higher tariffs than FTAs, resulting in larger welfare gains to the CU due to trade diversion, ultimately blocking Global Free Trade from the core. Our results also confirm both Bhagwati (1992), in that restrictions on tariffs set by a Customs Union can support Global Free Trade, and Yi (1996), in that Customs Unions are stumbling blocks to Global Free Trade.

Received 15 May 2006, Accepted 13 September 2006

\section{References}

Adams, R., P. Dee, J. Gali, and G. McGuire (2003) "Trade and Investment Effects of Preferential Trading Arrangements - Old and New Evidence" Productivity Commission 
Staff Working Paper, Canberra, May.

Andriamananjara, Soamiely (2002), "On the Size and Number of Regional Integration Arrangements: A Political Economy Model" Journal of International Trade and Economic Development 11:3 279-95.

Bagwell, Kyle and Robert Staiger (1998), "Will Preferential Agreements Undermine the Multilateral Trading System?" Economic Journal 108:449 1162-82.

Bhagwati, J. and A. Panagariya (1996) "Preferential Trading Areas and Multilateralism: Strangers, Friends, or Foes?" in Bhagwati and Panagariya (eds.) Free Trade Areas or Free Trade? The Economics of Preferential Trading Agreements Washington, D.C.: AEI Press.

Bhagwati, J. (July 1992) "The Threats to the World Trading System" World Economy 443456.

Bond, Eric and Constantinos Syropoulos (1996) "The Size of Trading Blocs, Market Power and World Welfare Effects" Journal of International Economics 40:3-4, 41137.

Burbidge, John B., James A. DePater, Gordon M. Myers, and Abhijit Sengupta (1997) “A Coalition-Formation Approach to Equilibrium Federations and Trading Blocs" American Economic Review 87:5 940-56.

Cadot, O., J. de Melo, and M. Olarreaga (1999) "Regional Integration and Lobbying for Tariffs Against Non-Members" International Economic Review 40:3, 635-57.

Campa, J.M., and Sorenson, T.L. (1996) "Are Trade Blocs Conducive to Free Trade?" Scandinavian Journal of Economics 98: 263-273.

Gatsios, K. and L. Karp (1995) "Delegation in a General Equilibrium Model of Customs Unions" European Economic Review 39: 319-33.

Grossman, Gene and Elhanan Helpman (1995), "The Politics of Free Trade Agreements" American Economic Review 85:4 667-90.

Harrison, G., T. Rutherford and I. Wooton (1993), "An Alternative Welfare Decomposition for Customs Unions" Canadian Journal of Economics 26:4 961-68.

Hertel, ThomasW. (ed.) Global Trade Analysis: Modeling and Applications. Cambridge: Cambridge University Press, 1995.

Hindley, B. and P. Messerlin (1993), "Guarantees of Market Access and Regionalism”, in $\mathrm{K}$. Anderson and R. Blackhurst (eds) Regional Integration and the Global Trading System London: Harvester-Wheatsheaf.

Johnson, H.G (1954) "Optimum Tariffs and Retaliation" Review of Economic Studies 21: 142-53; reprinted with amendments in: H.G. Johnson, ed., International Trade and Economic Growth London: George Allen and Unwin, 31-62.

Jomini, P.; McDougall, R.; Watts, G.; and Dee, P.S. The SALTER Model of the World Economy: Model Structure, Database and Parameters. Canberra: Industry Commission, 1994.

Kemp, Murray C., International Trade and National Welfare London: Routledge, 2001.

Kemp, Murray C. and Henry J. Wan (1976) "An Elementary Proposition Concerning the Formation of Customs Unions" Journal of International Economics 6:1 95-7. 
Kennan, J., and R. Riezman (1990) "Optimal Tariff Equilibria with Customs Unions." Canadian Journal of Economics 23: 70-83.

Kowalczyk, C. (1990) "Welfare and Customs Unions" NBER Working Paper 3476.

Krishna, P. (1998) "Regionalism and Multilateralism: A Political Economy Approach" Quarterly Journal of Economics 113:1, 227-51.

Krueger (1997) "Free Trade Agreements versus Customs Unions" Journal of Development Economics 54:1, 169-87.

Krugman, Paul R. (1991), "Is Bilateralism Bad?" in Helpman and Razin (eds.) International Trade and Trade Policy Cambridge, Mass.: MIT Press.

Levy, P. (Sept. 1997), "A Political-Economic Analysis of Free-Trade Agreements" American Economic Review 87:4, 506-19.

Markusen, J.R., J.R. Melvin, W.H. Kaempfer, and K.E. Maskus International Trade: Theory and Evidence. New York: McGraw Hill Inc., 1995.

Markusen, J.R. and R. M. Wigle (1989) "Nash Equilibrium Tariffs for the United States and Canada: The Roles of Country Size, Scale Economies, and Capital Mobility" Journal of Political Economy 97:2 368-386.

McMillan, J. (1993), "Does Regional Integration Foster Open Trade? Economic Theory and GATT's Article XXIV" in Anderson, K. and R. Blackhurst (eds.) Regional Integration and the Global Trading System London: Harvester-Wheatsheaf.

Melatos, M. and A. Woodland (2003) "Pareto Optimal Delegation in Customs Unions" University of Sydney Working Paper.

Panagariya, A. (2000) "Preferential Trade Liberalization: The Traditional Theory and New Developments" Journal of Economic Literature 38: 287-331.

Panagariya, A. (1999), "The Regionalism Debate: An Overview" World Economy 22:4, 477-511.

Panagariya, A. and R. Findlay (1996) "A Political Economy Analysis of Free Trade Areas and Customs Unions", in The Political Economy of Trade Policy: Essays in Honor of Jagdish Bhagwati, Feenstra, R. D. Irwin and G. Grossman (eds.), Cambridge, MA: MIT Press.

Panagariya, A. and Krishna P. (1998) "On the Existence of Necessarily Welfare-Enhancing Free Trade Areas", Working Paper 32, Centre for International Economics, University of Maryland.

Perroni, Carlo, and John Whalley (2000) "The New Regionalism: Trade Liberalization or Insurance?" Canadian Journal of Economics 33: 1-24.

Richardson, M. (1993) "Endogenous Protection and Trade Diversion" Journal of International Economics 34: 309-324.

Riezman, R. (1999) "Can Bilateral Trade Agreements Help Induce Free Trade?" Canadian Journal of Economics 32: 751-766. (1985) "Customs Unions and the Core" Journal of International Economics 19:355365.

Snape, R. (1993), "History and Economics of GATT's Article XXIV" in Anderson, K. and R. Blackhurst (eds.) Regional Integration and the Global Trading System London: 
Harvester-Wheatsheaf.

Syropoulos, C. (2002), "On Tariff Preferences and Delegation Decisions in Customs Unions: A Heckscher-Ohlin Approach" Economic Journal 112:481, 625-48.

Viner, Jacob (1950) The Customs Union Issue New York: Carnegie Endowment for International Peace.

Yi, S.-S. (1996), "Endogenous Formation of Customs Unions under Imperfect Competition: Open Regionalism is Good" Journal of International Economics 41: 151-75.

Zissimos, Ben and David Vines (2000) "Is the WTO's Article XXIV a Free Trade Barrier?" Centre for the Study of Globalisation and Regionalisation Working Paper No.39/00. 